INTERNATIONAL JOURNAL OF MULTIDISCIPLINARY RESEARCH AND ANALYSiS

ISSN(print): 2643-9840, ISSN(online): 2643-9875

Volume 05 Issue 03 March 2022

DOI: 10.47191/ijmra/v5-i3-05, Impact Factor: 6.072

Page No. 616-623

\title{
Implementation of HOTS-Based PJOK Learning (Higher Order Thinking Skill) at Junior High School, Sleman Central Sleman 2020
}

\author{
Chandra Richo Pratama ${ }^{1}$, Yudanto ${ }^{2}$, Amri Hartanto ${ }^{3}$, Betrix Teofa Perkasa Wibafiet Billy \\ Yachsie ${ }^{4}$, Andrian Rahman Ayudi ${ }^{5}$, Afeb Chesa Arianto ${ }^{6}$, Ujang Nurdin ${ }^{7}$, Galih Dewanti ${ }^{8}$ \\ $1,2,3,4,5,6,7$ Department of Sport Science, Yogyakarta State University, Yogyakarta Indonesia
}

ABSTRACT: This study aims to find out how well the implementation of HOTS (Higher Order Thinking Skill) based PJOK learning at SMP Negeri Zonasi Tengah Sleman 2020. This type of research is a quantitative descriptive study with a survey method. The population in this study were all PJOK teachers at the Zoning Middle School in Central Sleman, totaling 29 teachers, which were taken using a total sampling technique. Data collection techniques using a questionnaire. The data analysis technique used descriptive percentage analysis. The results showed that the implementation of HOTS (Higher Order Thinking Skill) based PJOK learning at the Zonasi Tengah Sleman Middle School in 2020 was in the "very poor" category of $0.00 \%$ ( 0 teachers), "less" of $51.72 \%$ ( 15 teachers), "enough" by $48.28 \%$ (14 teachers), "good" by $0.00 \%$ ( 0 teachers),

KEYWORDS- implementation, sport learning, HOTS-based

\section{INTRODUCTION}

The implementation of the 2013 Curriculum which is the reference for the learning process in educational units, according to policy, needs to integrate Strengthening Character Education (PPK). The integration is not as an additional program or an insertion, but as a unit of educating and learning for all education actors in the education unit. Presidential Regulation Number 87 of 2017 concerning Strengthening Character Education (PPK) makes character education an "educational movement under the responsibility of the education unit to strengthen the character of students through harmonization of heart, taste, thought, and sports with involvement and cooperation between education units, families, and communities as part of the National Movement for Mental Revolution (GNRM)" (Article 1, paragraph 1). This Presidential Regulation is the initial basis for putting character education back as the main soul in the implementation of education in Indonesia, reinforced by the issuance of Minister of Education and Culture Number 20 of 2018 concerning Strengthening Character Education in Formal Education Units. Strengthening Character Education is a national policy that must be implemented in every training in order to increase teacher competence.

In the 2013 curriculum learning there are several paradigm changes that have been used by teachers, these changes are intended to adapt to the demands of the times and prepare Indonesian human resources to be ready to compete in the future. Learning with the 2013 curriculum trains students to find out, not just be told about science, emphasizing language skills as a communication tool, carrier of knowledge, and logical, systematic, and creative thinking. Assessment is done by measuring students' thinking levels from low to high, not just memorizing concepts, measuring student work processes and results and using student learning portfolios.

The implementation of the 2013 curriculum (K-13) has consequences for teachers who have to be more qualified in carrying out learning activities. Why is that? Because K-13 mandates the application of a scientific approach (5M) which includes observing, asking, gathering information, reasoning/associating, and communicating. The government expects students to achieve various competencies by implementing Higher Order Thinking Skills (HOTS). These competencies are critical thinking (critical thinking), creative and innovative (creative and innovative), communication skills (communication skills), the ability to work together (collaboration) and confidence (confidence).

Students who have low-level thinking skills without higher-order thinking exercises cause the student's learning process to be incomplete. Therefore, an instrument is needed to support students to get used to higher-order thinking. The instrument is in 


\section{Implementation of HOTS-Based PJOK Learning (Higher Order Thinking Skill) at Junior High School, Sleman Central Sleman 2020}

the form of a test which in its completion requires higher-order thinking skills or what we are more familiar with HOTS-based tests.

Higher Order Thinking Skill (HOTS) is a higher order thinking skill that demands critical, creative, analytical thinking on information and data in solving problems (Barratt, 2014: 131). Higher order thinking is a type of thinking that tries to explore questions about existing knowledge related to issues that are not clearly defined and do not have definite answers (Haig, 2014: 143). Developing critical thinking requires practice finding patterns, compiling explanations, making hypotheses, generalizing, and documenting findings with evidence (Eggen, 2012: 261). This shows that learning that triggers students to think at higher levels requires the use of active student-oriented learning strategies, so that students have the opportunity to observe, ask questions, reason, experiment, and communicate. This kind of approach is in line with the expectations of the 2013 curriculum. The 2013 curriculum is a competency-based curriculum where the 2013 curriculum uses a scientific approach or commonly called the scientific approach, namely observing, asking, trying, reasoning and communicating. The purpose of using a scientific approach model based on the 2013 Curriculum Diktat module is intended to provide understanding to students in recognizing, understanding various materials using a scientific approach, that information can come from anywhere, anytime, not depending on direct information from the teacher. Therefore, the learning conditions that are expected to be created are directed at encouraging students to find out from various sources of observation, not being told (Majid \& Rochman, 2014: 70).

A teacher must have academic qualifications and know the basics of science, one of which is carrying out RPP preparation activities, so that in the implementation of teaching and learning activities the teacher can direct learning activities from beginning to end. This proves that a PJOK teacher must be able to prepare RPP properly and in accordance with K13 standards and it would be better if it was HOTS (High Order Thinking Skill) oriented, which stimulated students to understand more critically and be brave because HOTS-oriented teachers would tend to build class with representations, describing the material every time they teach and building relationships with students with activities that involve mentally trained, so that teaching and learning activities can run well.

This research was conducted in Sleman Regency. Sleman Regency is divided into 4 zones based on the Regulation of the Head of the Sleman Regency Education Office number: 01 of 2018, namely the west, east, middle, and north zones. In this study, the object of research is the Central Sleman Zoning. The Central Sleman zoning consists of 4 sub-districts, namely Tempel, Sleman, Mlati, and Ngaglik. The number of junior high schools in this zoning is 29 schools.

Based on the results of interviews conducted with one of the PJOK teachers, the teacher has attended several workshops on the preparation of the Learning Implementation Plan (RPP), the teacher also always makes and prepares the RPP at the beginning of the semester. The teacher used the lesson plans from the MGMP, but there was also one teacher who prepared some of the lesson plans he made himself. Another problem, related to the implementation of the 2013 curriculum in the field, still finds several obstacles in its implementation. Researchers see that PJOK teachers still do not understand the 2013 curriculum. This is because the teacher feels that he is almost retired, so that in teaching he still uses the 2006 curriculum teaching method and in understanding the 2013 curriculum it is only limited to knowing without practicing in the field. Observation while learning, the method used by the teacher has not led to learning methods related to HOTS. Interviews with several teachers stated that teachers did not know how to implement HOTS during learning.

In practice the teacher is still dominant in teaching (teacher center). This is in stark contrast to the modern era of 21st century skills, where students are more active in learning (student center). For example, in the practice of learning big balls such as basketball, the teacher explains a lot of material so that it drains lesson hours. The teacher only provides a final assessment of learning which is carried out through motor movement practice, the assessment should be carried out thoroughly from the affective and cognitive aspects. This has an impact on students not maximizing practice and feeling bored with PJOK subjects which should be fun.

The implementation of HOTS for most teachers is a challenge in itself, most teachers have relatively limited access to selfdevelopment. For some teachers, the implementation of HOTS learning is not an easy thing to do. HOTS for teachers who are able to have a high mindset and innovation power. Besides teachers need to really teach learning materials and strategies, teachers are also faced with environmental challenges and the intake of students they teach. Sometimes the teacher has succeeded in learning so that learning activities are interesting, but the responses of the students are still cold, and relatively passive. Starting from this problem, the background for conducting a research entitled "Implementation of HOTS-based PJOK learning (Higher Order Thinking Skill) at the Central Sleman Zoning Junior High School in 2020". 


\section{Implementation of HOTS-Based PJOK Learning (Higher Order Thinking Skill) at Junior High School, Sleman Central}

Sleman 2020

\section{METHODS}

This research is a descriptive research. Sugiyono (2007: 147), states that descriptive research is used to describe or describe the data that has been collected as it is. The method used in this research is a survey. Arikunto (2006: 152) states that a survey is a research approach that is generally used for extensive and large data collection. This study will describe the implementation of HOTS-based implementation in PJOK learning. The place of research is at SMP Negeri Zoning Central Sleman which consists of 4 sub-districts and 16 schools. This research was conducted in March 2020. Arikunto (2010: 173) states "the population is the entire research subject. The population in this study were PJOK teachers at the Zoning Middle School in Central Sleman, amounting to 29 teachers. Sugiyono (2007: 81) states that the sample is part of the number and characteristics possessed by the population. Sampling technique using total sampling. The instrument or tool used in this study was a closed questionnaire. Arikunto (2010: 168), states that a closed questionnaire is a questionnaire that is presented in such a way that the respondent only needs to put a checklist $(v)$ in the appropriate column or place, with direct questionnaires using a multilevel scale. The stratified scale in this questionnaire uses a modified Likert scale with four answer choices. The instrument grid for the Implementation of HOTS-Based PJOK Learning at the Zonal Middle Sleman Middle School in 2020 is presented in table 1 as follows:

Table 1. Instrument Grille

\begin{tabular}{|c|c|c|c|}
\hline Variable & Factor & Indicator & Item Number \\
\hline \multirow{21}{*}{$\begin{array}{l}\text { Implementation of HOTS- } \\
\text { based PJOK learning at the } \\
\text { Central Sleman Zoning Junior } \\
\text { High School in } 2020\end{array}$} & \multirow[t]{9}{*}{ Planning } & $\begin{array}{l}\text { 1. Observing the KD that will be used in the } \\
\text { HOTS muatan load }\end{array}$ & 1 \\
\hline & & $\begin{array}{l}\text { 2. Develop indicators based on operational } \\
\text { verbs containing HOTS }\end{array}$ & 2 \\
\hline & & 3. Learning objectives & 3 \\
\hline & & 4. Subject matter & 4 \\
\hline & & 5. Determining supportive learning methods & 5 \\
\hline & & 6. Designing learning steps & 6 \\
\hline & & 7. Select media & 7 \\
\hline & & 8. Designing the type of assessment & 8 \\
\hline & & 9. Determining the assessment instrument & 9 \\
\hline & \multirow[t]{9}{*}{ Implementation } & 1. Apperception & 10 \\
\hline & & 2. Warmup & 11 \\
\hline & & 3. Observe & 12,13 \\
\hline & & 4. Ask & 14,15 \\
\hline & & 5. Try & 16 \\
\hline & & 6. Associate & 17,18 \\
\hline & & 7. Accommodate & 19 \\
\hline & & 8. Reasoning & 20 \\
\hline & & 9. Communicating & 21 \\
\hline & \multirow[t]{3}{*}{ Evaluation } & 1. Cognitive & 22,23 \\
\hline & & 2. Affective & 24,25 \\
\hline & & 3. Psychomotor & 26 \\
\hline \multicolumn{3}{|l|}{ Amount } & 26 \\
\hline
\end{tabular}

The data collection technique that will be used is by giving a questionnaire to the respondents who are the subjects of the research. The mechanism is as follows: (1) Researchers ask for a research permit from the Faculty. (2) The researcher looks for data on PJOK teachers at the Zoning Middle School in Central Sleman (3) The researcher distributes a questionnaire to the respondents. (4) The researcher then collected the questionnaire and did a transcript of the results of filling out the questionnaire. (5) After obtaining research data, the researcher draws conclusions and suggestions. The data analysis technique in this study used descriptive percentage data analysis techniques. 
Implementation of HOTS-Based PJOK Learning (Higher Order Thinking Skill) at Junior High School, Sleman Central Sleman 2020

$$
\mathrm{P}=\% \frac{F}{N} X 100
$$

Description:

$\mathrm{M}$ : average value (mean)

$\mathrm{X}$ : score

$\mathrm{S}$ : standard deviation

Widoyoko (2011: 238) states that to determine the score criteria using the Ideal Norms Reference Assessment (PAN) in table 2 as follows:

Table 2. Rating Norms

\begin{tabular}{|l|l|}
\hline interval & Category \\
\hline $\mathrm{Mi}+1.8 \mathrm{Sbi}<\mathrm{X}$ & Very good \\
\hline $\mathrm{Mi}+0.6 \mathrm{Sbi}<\mathrm{X} \mathrm{Mi}+1.8 \mathrm{Sbi}$ & Good \\
\hline $\mathrm{Mi}-0.6 \mathrm{Sbi}<\mathrm{XMi}+0.6 \mathrm{Sbi}$ & Enough \\
\hline $\mathrm{Mi}-1.8 \mathrm{Sbi}<\mathrm{X} \mathrm{Mi}-0.6 \mathrm{Sbi}$ & Not enough \\
\hline $\mathrm{X} \mathrm{Mi}-1.8 \mathrm{Sbi}$ & Very less \\
\hline
\end{tabular}

(Source: Arikunto, 2010: 207)

Description:

$\mathrm{X}=$ average

$\mathrm{Mi}=$ (ideal max score + ideal min score)

Sbi $=1 / 6$ (ideal max score - ideal min score)

Ideal max score =highest score

Ideal min score =lowest score

\section{RESEARCH RESULTS}

Descriptive statistical data on the results of research on the implementation of HOTS-based PJOK learning at the Zonasi Central Sleman Middle School in 2020, the lowest score (minimum) was 50.00, the highest score (maximum) was 69.00, the mean (mean) was 60.03, the median was 58.00, frequently occurring value (mode) 56.00, standard deviation (SD) 5.02. The implementation of HOTS-based PJOK learning at the Central Sleman Zoning Middle School in 2020 can be presented in Figure 1 as follows:

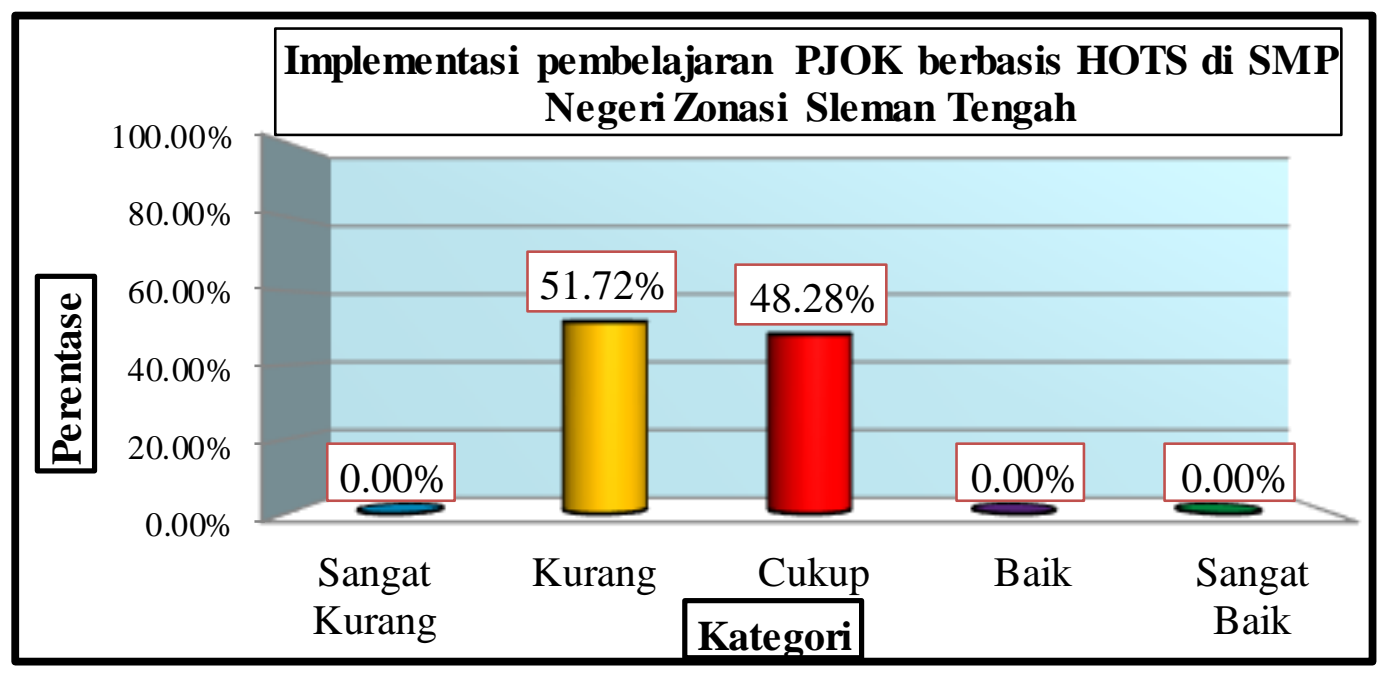

Figure 1. Bar Diagram of the Implementation of HOTS-Based PJOK Learning at the Central Sleman Zoning Junior High School in 2020

Based on Figure 1 above, it shows that the implementation of HOTS-based PJOK learning at the Zoning Middle Sleman Middle School in 2020 is in the "very poor" category of $0.00 \%$ (0 teachers), "less" of $51.72 \%$ (15 teachers), "enough" is $48.28 \%$ (14 
Implementation of HOTS-Based PJOK Learning (Higher Order Thinking Skill) at Junior High School, Sleman Central Sleman 2020

teachers), "good" is $0.00 \%$ ( 0 teachers), and "very good" is $0.00 \%$ ( 0 teachers). Based on the average value, which is 60.03 , in the "enough" category.

\section{Planning Factor}

The implementation of HOTS-based PJOK learning at SMP Negeri Zoning Central Sleman in 2020 based on planning factors can be presented in Figure 2 as follows:

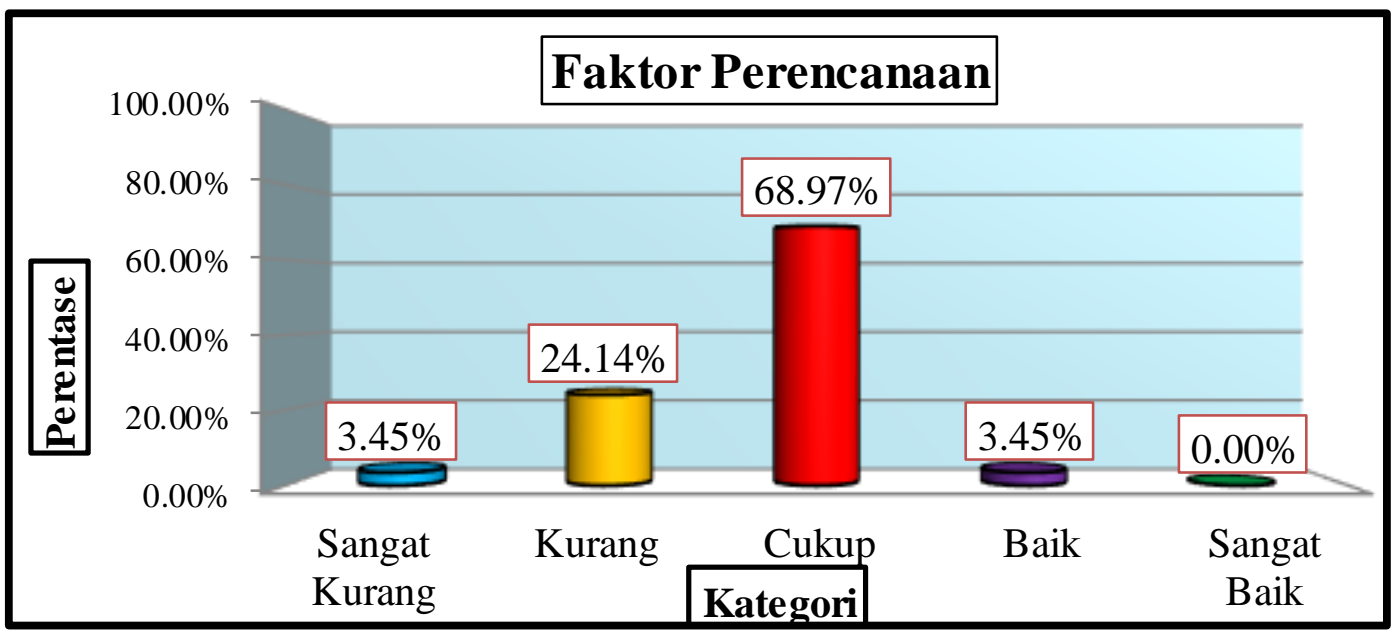

Figure 2. Bar Chart Based on Planning Factors

Based on the table above, it shows that the implementation of HOTS-based PJOK learning at the Zonal Central Sleman Middle School in 2020 based on planning factors is in the "very poor" category of $3.45 \%$ ( 1 teacher), "less" of $24.14 \%$ (7 teachers). ), "enough" 68.97\% (20 teachers), "good" 3.45\% (1 teacher), and "very good" 0.00\% (0 teachers). Based on the average value, which is 20.90 , the implementation of HOTS-based PJOK learning at the Zoning Middle School of Sleman Tengah in 2020 is based on planning factors in the "enough" category.

\section{Implementation Factor}

The implementation of HOTS-based PJOK learning at the Central Sleman Zoning Middle School in 2020 based on implementation factors can be presented in Figure 3 as follows:

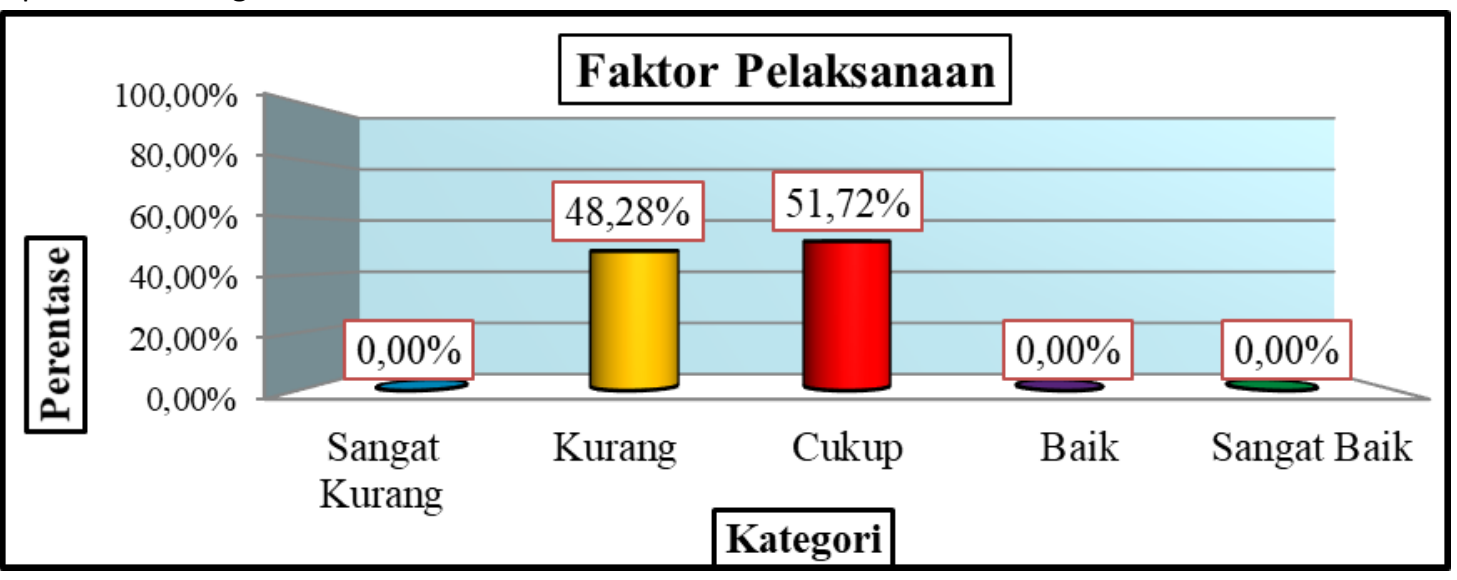

Figure 3. Bar Chart Based on Implementation Factors

Based on the table above, it shows that the implementation of HOTS-based PJOK learning at the Zonal Central Sleman Middle School in 2020 based on the implementation factor is in the "very poor" category of $0.00 \%$ (0 teachers), "less" of $48.28 \%$ (14 teachers), "enough" at 51.72\% (15 teachers), "good" at 0\% (0 teachers), and "very good" at 0.00\% (0 teachers). Based on the average value, which is 27.52, the implementation of HOTS-based PJOK learning at the Zoning Middle School of Sleman Tengah in 2020 is based on the implementation factor in the "enough" category.

\section{Evaluation Factor}

The implementation of HOTS-based PJOK learning at the Central Sleman Zoning Junior High School in 2020 based on evaluation factors can be presented in Figure 4 as follows: 


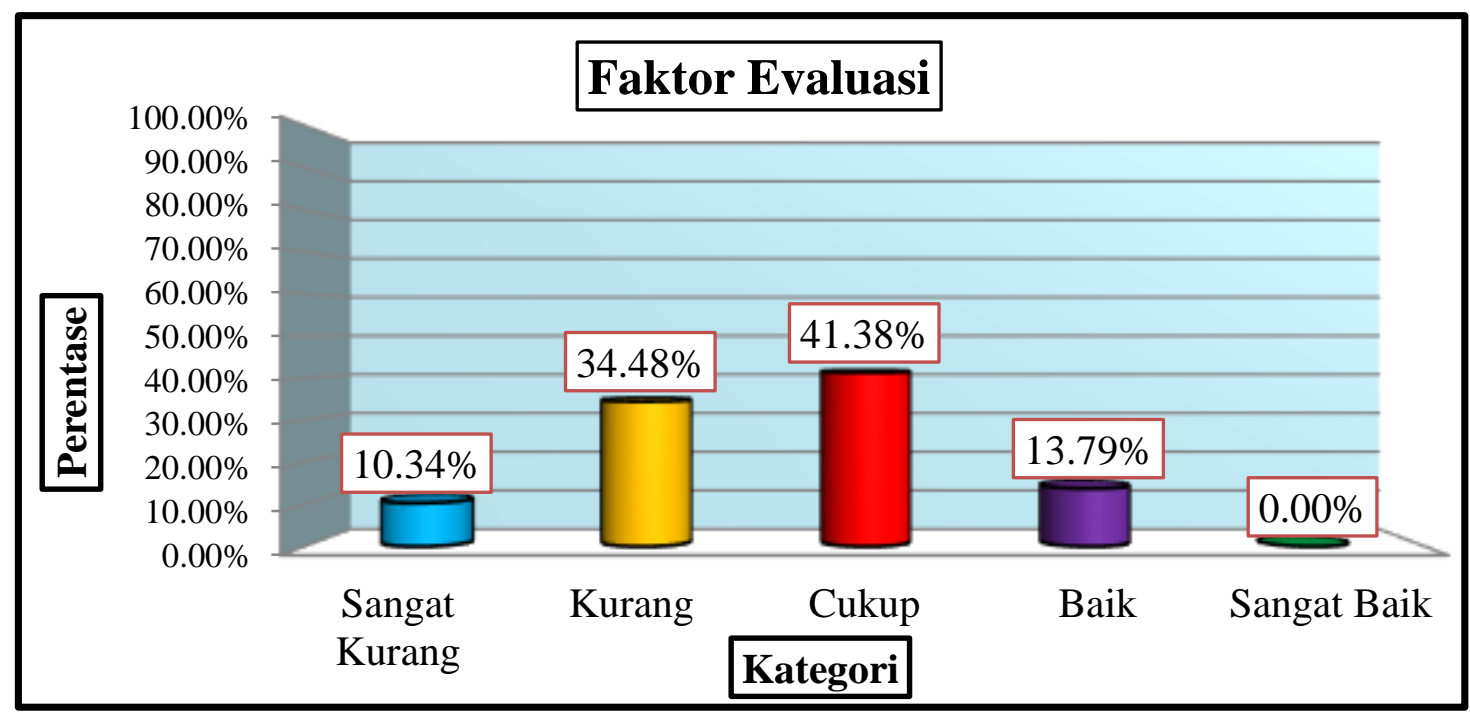

Figure 4. Bar Chart Based on Evaluation Factors

Based on the table above, it shows that the implementation of HOTS-based PJOK learning at the Zonasi Tengah Sleman Middle School in 2020 based on evaluation factors is in the "very poor" category of $10.34 \%$ ( 0 teachers), "less" of $34.48 \%$ (10 teachers ), "enough" by $41.38 \%$ ( 12 teachers), "good" by $13.79 \%$ ( 4 teachers), and "very good" by $0.00 \%$ ( 0 teachers). Based on the average value, which is 11.62, the implementation of HOTS-based PJOK learning at the Zoning Middle School in Sleman Tengah in 2020 is based on the evaluation factor in the "enough" category.

\section{DISCUSSION}

This study aims to determine the implementation of HOTS-based PJOK learning at the Zonasi Tengah Sleman Middle School in 2020, which was expressed by a questionnaire totaling 26 items, and was divided into three factors, namely planning, implementation, and evaluation factors. Based on the results of the study, the implementation of HOTS-based PJOK learning at the Zoning Middle Sleman Middle School in $\mathbf{2 0 2 0}$ was in the sufficient category. In detail, there are at most in the less category there are 15 teachers or $51.72 \%$, then in the sufficient category there are 14 teachers or $48.28 \%$. The figure of an educator or teacher is very important to realize a better education. As stated by Fetura \& Hastuti (2017: 51) that teachers are professional educators with the main task of educating, teaching, guiding, directing, training, assessing,

Based on the results above, it shows that the implementation of HOTS-based PJOK learning at the Zoning State Middle School in Sleman Tengah is still not maximally applied during learning. Teachers should be able to change the pattern of learning comprehensively based on higher-order and activity-based thinking skills. The way that can be done to adopt this is by developing lesson plans, learning implementation, and authentic HOTS-based assessments for each lesson. However, in practice the development of planning, implementation, and authentic HOTS-based assessment is not an easy thing for teachers to implement. In addition to teachers having to really master the material and learning strategies, teachers are also faced with challenges with the environment and the intake of the students they teach.

This refers to the statement that, "Science education worldwide reforms are derived from the constructivist views of teaching and learning. These reforms are explicitly ask teachers to change their teaching strategies by shifting the emphasis from traditional textbook-based and rote learning, to exploration and inquiry-based learning situated in real-world phenomena", (Miri, 2007: 354). That is, education reform around the world stems from a constructivist view of teaching and learning. This reform explicitly calls for teachers to change their teaching strategies by shifting the emphasis from traditional text-based and rote learning, to exploration and inquiry-based learning that is oriented towards real-world phenomena.

HOTS-based learning in the 2013 Curriculum can be done by compiling competency achievements that not only answer at levels C-1 (knowing), C-2 (understanding), and C-3 (applying), but also at level C-4 (synthesis/ analysis), C-5 (evaluation), and C-6 (creative). Learning to think critically as a feature of HOTS is not like learning about the material directly. Critical thinking is related to how to solve interrelated problems. Critical thinking allows students to find the truth in the midst of events and information that surrounds them every day. Through critical thinking, students will experience a systematic process that allows them to formulate and evaluate their own beliefs and opinions. 


\section{Implementation of HOTS-Based PJOK Learning (Higher Order Thinking Skill) at Junior High School, Sleman Central Sleman 2020}

Implementation of HOTS-based PJOK learning at the Zoning Middle School in Central Sleman in 2020 based on planning factors in the "enough" category. The HOTS assessment comes from a HOTS-based learning plan with the characteristics of one of the indicators and learning objectives used, which are dominant using cognitive level 3, namely C4-C6. Then from the goals that have been set, learning steps are made that reflect HOTS learning. Learning planning must begin with an understanding of the meaning and purpose, as well as mastering the theoretical and practical elements contained in it. The ability to make plans is the first step for teachers and prospective teachers, as well as the estuary of all theoretical knowledge, basic skills, and in-depth understanding of learning objects and learning situations. Learning planning is designed in the form of a syllabus and lesson plan (RPP) which refers to the Content Standards. Learning planning includes the preparation of learning implementation plans and preparation of learning media and resources, learning assessment tools, and learning scenarios. The preparation of the syllabus and lesson plans is adjusted to the learning approach used.

The implementation of HOTS-based PJOK learning at the Central Sleman Zoning Junior High School in 2020 is based on the implementation factor in the "enough" category. In accordance with Permendikbud, Learning Implementation (RPP) is a face-toface learning activity plan for one or more meetings. RPP was developed from the syllabus to direct students' learning activities in an effort to achieve Basic Competence (KD). Every educator in the education unit is obliged to compile a complete and systematic lesson plan so that learning takes place interactively, inspiring, fun, challenging, efficient, motivating students to participate actively, and providing sufficient space for initiative, creativity, and independence according to their talents, interests. , and the physical and psychological development of students.

The implementation of HOTS-based PJOK learning at the Zoning Middle Sleman Middle School in 2020 is based on the evaluation factor in the "enough" category. Assessment and evaluation of learning needs to be done because with the results of the assessment students can find out their strengths and weaknesses in learning so far. Because the benefits of assessment for students are that students can find out how far they have succeeded in following the learning delivered by the teacher (Widoyoko, 2011). According to Permendikbud number 22 of 2016, the assessment of the learning process uses an authentic assessment approach that assesses the readiness of students, processes, and learning outcomes as a whole. The integrated assessment of the three components will describe the capacity, style, and learning outcomes of students who are able to produce an instructional effect (instructional effect) on the knowledge aspect and the nurturing effect on the attitude aspect. The results of the authentic assessment are used by teachers to plan learning remedial programs, enrichment, or counseling services. In addition, the results of the authentic assessment are used as material to improve the learning process in accordance with the Educational Assessment Standards.

Evaluation of the learning process is carried out during the learning process using the following tools: observation sheets, peer questionnaires, recordings, anecdotal notes, and reflections. Evaluation of learning outcomes is carried out during the learning process and at the end of the lesson unit using methods and tools: oral/action tests, and written tests. The final evaluation results are obtained from a combination of process evaluation and evaluation of learning outcomes.

\section{CONCLUSIONS}

Based on the results of data analysis and discussion, it can be concluded that the implementation of HOTS (Higher Order Thinking Skill) based PJOK learning at the Zonasi Tengah Sleman Middle School in 2020 is in the "very poor" category of 0.00\% (0 teachers), "less" 51.72\% (15 teachers), 48.28\% (14 teachers), "good" 0.00\% (0 teachers), and "very good" $0.00 \%$ (0 teachers).

\section{REFERENCES}

1) Afandi \& Sajidan (2018). Stimulation of higher order thinking skills. Surakarta: Publisher and Printing UNS.

2) Arikunto, S. (2010). The research procedure is a practical approach. Jakarta: PT Bina Aksara.

3) Barrat, C. (2014). Higher order thinking and assessment. International Seminar on current issues in Primary Education: PGSD Study Program, University of Muhammadiyah Makassar.

4) Eggen, P. K. (2012). Learning strategies and models. Jakarta: PT. Index.

5) Fetura, A \& Hastuti, T.A. (2017). Students' understanding of the competence of physical education teachers. Indonesian Journal of Physical Education, 13 (2), pp. 50-57.

6) Haig, Y. (2014). Higher order thinking and assessment. International Seminar on current issues in Primary Education: PGSD Study Program, University of Muhammadiyah Makassar.

7) Majid, A., \& Rochman, C. (2014). Scientific approach in implementing the 2013 curriculum. Bandung: PT Pemuda Rosdakarya. 
Implementation of HOTS-Based PJOK Learning (Higher Order Thinking Skill) at Junior High School, Sleman Central Sleman 2020

8) Miri, et al. (2007). Purposely teaching for the promotion of higher-order thinking skills: a case of critical thinking. Res Sci Educ, 37(1), 353-369.

9) Presidential Regulation Number 87 of 2017 concerning Strengthening Character Education (PPK).

10) Sugiyono. (2007). Research methods are quantitative, qualitative, and R\&D. Bandung: Alphabeta.

11) Widoyoko, Eko Putro. (2011). evaluation of learning programs; practical guide for educators and prospective educators. Yogyakarta: Student Library. 